\title{
CBR1 wt Allele
}

National Cancer Institute

\section{Source}

National Cancer Institute. CBR1 wt Allele. NCI Thesaurus. Code C118564.

Human CBR1 wild-type allele is located in the vicinity of $21 \mathrm{q} 22.1$ and is approximately $3 \mathrm{~kb}$ in length. This allele, which encodes carbonyl reductase [NADPH] 1 protein, is involved in the reduction of a wide variety of carbonyl compounds. 